\title{
The Moderator Effect of the Perception of Value Co-Creation on the Relationship between Hotel Brand Equity and WOM
}

\author{
Abdullah Uslu \\ Akdeniz University, Turkey \\ auslu@akdeniz.edu.tr \\ Gözde Seval Ergün \\ Akdeniz University, Turkey \\ gates@akdeniz.edu.tr
}

In the current conjuncture, when the competitive environment is getting ever fiercer, the importance of creating brand value and the effect of wom in all processes before/after a purchase have been grasped. Along with this, in the service sector, where the customer-employee relationship is dense, applications regarding the perception of value creation have started to be used in an increasing manner. For this reason, the aim of the study is to determine the effect of the brand equity of foreign tourists on wOM and whether there is a moderator effect of the Perception of Value Co-Creation on this effect. The population of the study is comprised of foreign tourists coming to Marmaris, Turkey. On the 358 surveys gathered from foreign tourists, EFA, CFA, second-order CFA analyses, path analyses and Slope tests have been carried out. Consequently, it has been determined that hotel brand equity has effects on the perception of value co-creation and WOM, and that perception of value co-creation has effects on шом. Also, in the relationship between foreign tourists' hotel brand equity and woM, it has been determined that there is a moderator effect on the perception of value co-creation.

Keywords: hotel brand equity, wom, perception of value co-creation, Marmaris

(cc)BY-SA https://doi.org/10.26493/2335-4194.14.149-164

\section{Introduction}

Enterprises are proving inadequate with regard to dealing with increasingly challenging and competitive conditions by using conventional marketing techniques. It is considered that new customers will be gained by the contemporary marketing approach, sustenance will be maintained for the customers gained, and in addition the permanence of existing customers will be ensured. Ensuring customer sustenance will only be possible if customers feel valued during/after the purchasing of the goods or service. Grönroos (2000) emphasizes that brand equity is a result of the brand relationship which is constantly developed with the customer.

According to the current perspective of salespeople, Word-of-Mouth communication (том) is seen as an important topic which plays a key role in marketing, and it is known that it has substantial effects and consequences (Albarq, 2014). woM, which determines behaviour and has great interpersonal effect, is seen as one of the most important information resources of the consumer. Salespeople who wish to catalyze and manage these interactions that will benefit them have started to think about and develop strate- 
gies in order to manage this interpersonal effect. These effects are seen as important for tourism enterprises, where it is difficult to evaluate the product before it is consumed (Ergün \& Akgün, 2016). According to Jalilvand and Samiei (2012), шом is an important method that is used for influencing tourists to endow them with a high coefficient effect.

The effect of wом on brand equity (Yang et al., 2015; Murtiasih et al., 2014; Moise et al., 2019) and increasing value co-creation (Seifert \& Kwon, 2020) can be observed in previous studies. In this study, the moderator role of value co-creation differentiates this research from the others. While referring to the effect of brand equity on wom, the enriching effect of value co-creation, which is a third variable, makes the results of the research notable. The businesses that want to be different and connect with consumers by creating a value for them are trying to form strong and valuable brands (Marangoz \& Aydın, 2021). Considering the positive results achieved without creating value, it is of great importance for accommodation businesses to learn how to manage this process, which requires active customer participation. It is easily understood that the creation of such value depends largely on how the hotel is perceived (Cantallops, 2019). In order to ensure brand equity, the importance of offering value to the customer and matching this value with the customer perception has been increasingly recognized. Within this context, the finding that brand equity and value co-creation will together have a stronger effect is thought to be a guide, especially for businesses. What is more, in the literature review, no study was found in which these variables were simultaneously examined. Accordingly, it is thought that the research will fill the gap in the literature and be a guide for future studies.

The main aim of this study is to measure the effect of hotel brand equity on wом and determine whether value co-creation has a moderator effect in this process. Prior to the research analyses (customer-based), a literature review has been provided in order to ensure understanding of the theoretical bases for the concepts of hotel brand equity, wом and perception of value co-creation, and to develop hypotheses. Subsequently, in order to achieve the aim of the study, EFA, CFA, second-order CFA analyses, path analyses and Slope tests have been carried out in the methodology section.

\section{Literature Review \\ WOM}

wom can be defined as an interpersonal communication occurring informally between a source and a buyer that does not have a commercial agenda attributable to a brand, product or enterprise (Anderson, 1998). When wo m's effects are taken into consideration, it is assumed that it has a mysterious power and is a tool that works to determine the satisfaction or dissatisfaction created after a product experience (Gremler, 1995).

wOM, which is seen as a popular market phenomenon by writers (Laczniak et al., 2001), is not limited to face-to-face interaction, and can be transferred by interactive tools such as the telephone and internet (Dellarocas, 2003). Also, in online and offline communication, opinion leaders and reliable and knowledgeable individuals comment on content and influence those searching for opinions (Lee et al., 2011).

As the complexity of products increases and their evaluation becomes harder, or when it is considered risky to purchase, the rate of individuals who need recommendations from people they trust increases. It is seen that people have a tendency to follow users' recommendations rather than messages conveyed through advertisement (Barlow \& Moller, 2008). In fact, technically, wom can be used in order to reduce ambiguity with regard to goods or services and minimize risk (Abubakar, 2016). Those services are intangible renders pre-trials impossible. For this reason, wom plays an important role in the decisions taken regarding service businesses. Also, wом becomes especially important when the service provided is complex or it has a high perception of risk (Zeithaml et al., 1996). Since tourism services are one of those that cannot be evaluated prior to purchase, they are considered high risk purchases (Sotiriadis \& Zyl, 2013).

\section{Hotel Brand Equity}

Brand is one of the fundamental marketing concepts. Until recently, the following definition of the concept 
of brand has been dominant in both the general marketing and tourism marketing literature. Kotler (2000, p. 404) defines 'brand' as follows: 'A name, term, sign, symbol, design or a combination of these that define a seller or seller group's goods or services and differentiates it from others.' However, Grönroos (2000) claims that this definition takes the concept of brand only with a unilateral perspective and excludes the consuming process and customer. According to this perspective, if a brand is to be built, the customer is the one who does that. In this case, the role of the salesperson is to ensure communication support by using various planned marketing communication tools and to create frameworks in the minds of customers in order to develop a brand.

It is known that right branding bears a critical importance for organizational success (Huang \& Cai, 2015). Brand managers are responsible generally for creating a strong brand and sustaining it, while they also have to find ways to measure brand value (Kayaman \& Arasli, 2007). Brand value is the most prevalent concept that is used to represent brand performance and is measured as financial value in the organizational statement (Pike, 2010). There are three different perspectives regarding brand equity in the literature. These are the finance-based approach, customerbased approach and mixed approach (Bailey \& Ball, 2006; Kim \& Kim, 2005). Researchers taking the financial approach into consideration define brand equity as the cash flow created by a product's brand name (Akgün \& Akgün, 2014). This approach is criticized since it cannot encapsulate all factors constituting a brand's power and ignores consumer behaviour. Customer-based brand equity, as the other approach acknowledged in brand equity, regards the way goods and services are perceived and evaluated and proves a determining factor in subsequent purchases (Broyles et al., 2010). With this perspective, Keller (1993) focuses on what the customer learned, saw, heard and felt about the brand. Lastly, a mixed approach comprises both the market power and the financial value of the brand (Seric et al., 2017). The reason behind the concept of brand being measured with the customerbased brand equity is the change oriented towards a customer-based approach from a product-based ap- proach in the service marketing paradigm (Grönroos, 2000). It is considered that the conceptualization of brand equity with the customer perspective will be beneficial for both marketing strategies and the decision-making process in management (Keller, 1993) and that the brand is more valuable relative to its raw financial evaluation (Pike, 2009).

When the studies focused on brand equity in the literature are reviewed, it is seen that the conceptual framework underlying all of these studies is based on Aaker (1991) and Keller (1993). Aaker (1991) identified four main brand value variables in their study. These are brand loyalty, perceived quality, brand image and brand awareness, respectively. Keller (1993, p. 8) defines brand value as the different effect of the brand knowledge on the customer reaction to the brand marketing' and the concept of brand is evaluated in two dimensions: brand awareness and brand image. In addition to these studies, Yoo and Donthu (2001) have developed the multi-dimensional consumer-based brand equity scale.

Although here are a number of different definitions with regard to the concept of customer-based brand equity, there is a common consensus on the brand value's being comprised of the four perceived dimensions suggested by Aaker (1991). These dimensions are brand awareness, brand image, perceived quality and brand loyalty as a relational variable (Seric et al., 2018).

The concept of brand equity is seen as quite important in the tourism sector as well as other service sectors. According to certain studies carried out on the concept of brand in the literature, it is claimed that brand hotels provide better performance in comparison to others (Forgacs, 2003). Also, it is contended that there is a positive relationship between the brand value success of luxury hotels and their financial performances (Kim \& Kim, 2005). The main topic of the studies in the concept of hotel brand equity is defined by Prasad and Dev (2000, pp. 23-24) as 'the positive or negative attitudes and perceptions affecting customers' reservation.'

The increasing international activities of accommodation businesses render it necessary to carry out more research on customer-based brand equity. Destinations and hotel enterprises that endeavour to dom- 
inate other countries in the tourism sectors place more importance on the issue of branding in comparison to the past (Çinar et al., 2019). Hotel enterprises that take on the heavy load of the sector are dramatically affected by global developments and lean heavily on the matter of creating brand value in order to turn this situation into opportunity. All positive or negative attitudes and perceptions affecting a customer in preferring a hotel brand represent brand equity. Whereas a customer's good experience in a brand hotel increases brand equity, a bad experience damages brand equity (Prasad \& Dev, 2000). It is considered that as hotels are becoming brands, their customer perceptions will be affected, and positive mental attitudes will be ensured. Furthermore, instead of advertisements as mass media tools that are losing their validity, the advantages of wom established as a result of branding will be utilized. Brand equity does not necessitate a person's experiencing a brand in order to have a brand impression; that they are subjected to certain recommendations can prove adequate on its own (Prasad \& Dev, 200o). In addition to all of these, customer-based brand equity is considered an effective tool in hotel managers understanding their own brands (Çınar et al., 2019).

There are studies in the literature that put forth the relation between brand loyalty, brand image, perceived quality, brand awareness and шом (Murtiasih et al., 2014; Moise et al., 2019). Ansary and Hashim (2018), in their study, measured the moderator effect of wom on the relations between brand value components and brand value. $\mathrm{Xu}$ and Chan (2010), in a study carried out on hotel brand equity, state that wom has a strong effect on brand awareness and brand image. Yang et al. (2015), in their study, concluded that wом has an important effect on destination brand value. According to the results obtained by Sofiane (2019), it is seen that all dimensions of brand equity have a positive effect on wom.

Although the concept of brand equity was studied frequently by correlation with different variables within the context of destination (Boo et al., 2009; Chekalina et al., 2018; Davras, 2019; Dedeoğlu et al., 2019; Kim et al., 2017; Pike \& Bianchi, 2016) and hotel (García et al., 2018; Seric et al., 2017; Seric et al., 2018;
Seric \& Gil-Saura, 2019; Sijoria et al., 2019; Sürücü et al., 2019; Uslu et al., 2020), no studies have been encountered that address the relationship between perceived value co-creation and wом. In the light of this information, the first hypothesis has been put forth as follows.

$\mathrm{H} 1$ Hotel Brand Equity has a positive and significant effect on Wом.

\section{Perception of Value Co-Creation}

The nature of the concept of value has been discussed since Aristoteles and it is known that it has two meanings acknowledged as 'changing value' and 'value in use.' Changing value is that emerging from the product-dominant logic. According to this perspective, the value is created by the company (produced) and generally distributed to the market via goods or monetary exchange. In the service-dominant (s-D) logic, the concept of value refers to value in use (Vargo et al., 2008). This approach entails more than merely proving to be customer oriented. Here, collaborating with the customers, learning from customers and adapting to their individual and dynamic needs become prominent. This service-dominant logic expresses that value is defined by the consumer and created with them instead of by output (Vargo \& Lusch, 2004). Despite the consensus that the customer has a more active role and that the value is subjective, there is no consensus yet on the definition of the concept and the processes inherent in this concept (Alves et al., 2016).

Businesses can present services as only value propositions and this becomes the input of value realization. It is seen that value realization depends on the participation of customers in the service process. Beneficiaries (namely, customers) determine whether value is actually created, and this situation renders the service specific to the beneficiary (Cabiddu et al., 2013).

The concept of value co-creation is correlated with developing a unique competence by using organizational resources and technological capabilities aiming to meet customers' demands more efficiently and thereby gaining a competitive advantage (Maduka, 2016). Among the propelling forces of the concept, there are the developments and maturation in technology, accelerated consumer information and expec- 
tations as well as the logic of integrating consumer needs and expectations in the value chain of a company (Chathoth et al., 2016).

From an organizational standpoint, in the perception of value co-creation, the participation of managers and employees is needed as much as that of the customers, although it should not be forgotten that the primary and ultimate actor is always the customer. Managers are held responsible for designing and implementing a process that allows and even encourages customers to take an active role. Within this context, it is seen as indispensable to train and improve employees in achieving success (González-Mansilla et al., 2019). For this reason, enterprises need to train employees in the importance of customer experience and on value creation resourcing from these experiences (Chathoth et al., 2016).

Grönroos (2011) considers the expression '[c]ustomer is always a value creator' to be true, yet incomplete. They express that this definition is too basic to account for theoretical development or practical decision making. It is not entirely clear what value creation means. Does the definition of value in this expression refer to the customer creating value in use or a more comprehensive process where the customer is creating value in use? This is only a single part of the ambiguity. Generally, in the service-dominant logic, value creation refers to a process encompassing everything, and it is created not only by the customers but by different stakeholders, including the enterprise and the customer (Grönroos, 2011).

The concept of the perception of value co-creation focuses on enhancing the customer's experience by way of improvements in the process of service provision or by adjusting the service individually according to the needs of the customer. The situation in question is especially considered important for luxury hotels (González-Mansilla et al., 2019). While cocreation is examined in unison in various areas involving strategy, management and marketing, that it is implemented within the context of tourism and hotel administration as a proactive service provider gains a special importance (Chathoth et al., 2016).

Chekalina et al. (2014) carried out a study in order to test the relationship between customer-based brand equity and the perception of co-creation of value. In the study conducted by González-Mansilla et al. (2019), it was determined that the customer perception regarding the process of value co-creation has a positive effect on the brand value. Xu et al. (2019) examined the customer-based brand equity theory for destinations based on the value co-creation theory. In the study, empirical results were obtained that will encourage brand value management and the participation of tourists in value co-creation activities. According to the findings in Frías Jamilena et al's (2017) study, it is put forth that the value co-creation perception is a premise of the customer perceiving the destination brand value to be higher. In the study conducted by Seifert and Kwon (2020), it was concluded that the e-wом has a higher effect on the brand value and value co-creation loyalty behaviour. As a result of the literature review, the second and third hypotheses have been constituted.

$\mathrm{H} 2$ Hotel Brand Equity has a positive and signifcant effect on the perception of value co-creation.

$\mathrm{H} 3$ Perception of value co-creation has a positive and significant effect on

As a result of the study conducted by Prebensen et al. (2016) on tourist experiences, it was determined that there is a moderator effect on the relation of perceived value and satisfaction. Chou et al. (2018) examined the moderator effect of the value co-creation variable in their studies conducted on travel agencies. The fourth hypothesis has been put forth in light of the studies reviewed in the literature review.

H4 Perception of value co-creation has a moderating effect on the relationship between Hotel Brand Equity and Wом

\section{Methods}

The Aim of the Study and the Conceptual Model

The aim of this study is to: (1) determine the brand value perceptions of foreign tourists coming to Marmaris on the perception of value co-creation and WoM, (2) ascertain the effect of tourists' perception of value co-creation on wом, and (3) determine the moderator effect of perception of value co-creation on the relation between hotel brand equity and wом. For this 


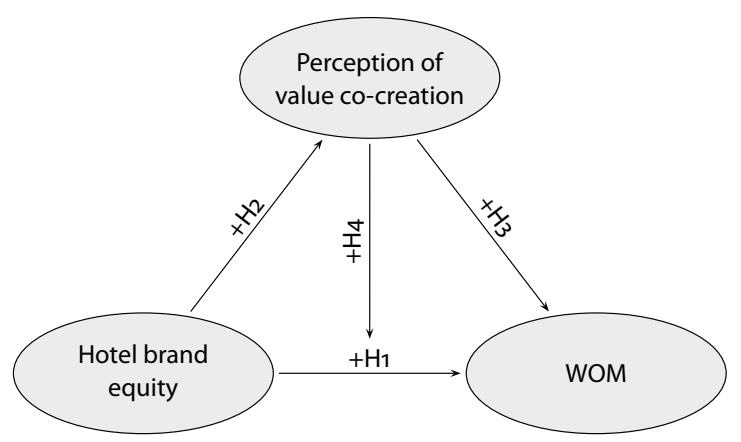

Figure 1 The Conceptual Model

reason, by utilizing the studies in the relevant literature (Prebensen et al., 2016; Ansary \& Hashim, 2018; Sofiane, 2019; Moise et al., 2019; González-Mansilla et al., 2019; Seifert \& Kwon, 2020; Xu et al., 2019), the model of the study has been created as in Figure 1.

The Method, Population and Sample of the Study In this study, the quantitative research survey method has been used in order to determine the effects of hotel brand equity dimensions (brand awareness/recognition, brand association/image, perceived quality and loyalty) on шом and the moderator role of the perception of value co-creation on the relations between these variables. This study is important in terms of its uniqueness in the literature, for explicating the relations between these variables, and for understanding the moderator role of perception of value co-creation.

In this study based on hypothesis testing, a quantitative approach has been adopted and the survey method was used in data collection. 10 questions were created for the study survey in order to determine the socio-demographical characteristics of the tourists. For the 11 questions created with the sub-dimensions of hotel brand equity, surveys created by GonzálezMansilla et al. (2019) have been adapted. Statements comprised of 3 questions for the wom variable have been adopted from the study carried out by Yazgan et al. (2014). 12 questions created with the sub-dimensions for the perception of value co-creation have been adopted from the surveys created by González-Mansilla et al. (2019). A 5-point Likert scale has been used in the survey as $1=$ Completely disagree, $5=$ Com- pletely agree. The survey questions were prepared by three researchers who are experts in the area of tourism and marketing. After the questions were examined, the statements in the survey were controlled by a native English speaker expert.

The study was carried out by two surveyors who knew the aim of the study, and one of the authors, with convenience sampling, between 1 May and $1 \mathrm{Au}-$ gust 2019. While foreign tourists were leaving the hotel enterprises that they stayed in, 370 surveys were elicited from those tourists by informing them about the aim of the study in the hotel lobby. 12 surveys that were empty or understood to be erroneous have been excluded and the rest, 358 surveys, have been included in the study. These 358 surveys can be considered adequate in representing the population (Bryman \& Cramer, 2001).

The population of the study is comprised of foreign tourists visiting hotel enterprises in Marmaris. The number of accommodation facilities with ministry accreditation operating in Marmaris is 200. According to the GEтов (South Aegean Hotel Enterprises' Union), the number of foreign tourists visiting Marmaris is around 900 thousand people per annum.

Percentage and frequency, along with exploratory factor analysis in SPSs 22.00, was applied to the data obtained and subsequently the CFA, second-order CFA and structural model analysis were carried out in the A MOS 22.00 package software. Subsequently, the Slope test was utilized in determining the moderator effect.

\section{Results}

In order to evaluate the research findings, primarily the lost data, outlier value, homogeneity and reliability oriented towards the raw data obtained from the survey needed to be tested. Therefore, when the lost data for the study was gleaned, it was seen that the rate of empty items in the survey was not higher than $15 \%$ (Tabachnick \& Fidell, 2007) and it was not replaced with any data.

Checking at the outlier values for the data; ' $\mathrm{Z}$ ' and ' $\mathrm{T}$ ' scores has been found that there is no value beyond +3 and -3 . As a result of the homogeneity test, data was determined to be homogenous since the $p$-value 
Table 1 Demographic Characteristics of Foreign Tourists

\begin{tabular}{|c|c|c|c|}
\hline Category & Item & $n$ & $\%$ \\
\hline \multirow[t]{2}{*}{ Gender } & Female & 166 & 46.4 \\
\hline & Male & 192 & 53.6 \\
\hline \multirow[t]{4}{*}{ Nationality } & British & 226 & 63.1 \\
\hline & Dutch & 93 & 26.0 \\
\hline & Swedish & 27 & 7.5 \\
\hline & Others & 12 & 3.4 \\
\hline \multirow[t]{3}{*}{ Marital Status } & Single & 164 & 45.8 \\
\hline & Married & 143 & 39.9 \\
\hline & Married with children & 51 & 14.2 \\
\hline \multirow[t]{5}{*}{ Education status } & Primary School & 76 & 21.2 \\
\hline & High School & 108 & 30.2 \\
\hline & University & 123 & $34 \cdot 4$ \\
\hline & Master's degree & 13 & 3.6 \\
\hline & No response & 38 & 10.6 \\
\hline \multirow{4}{*}{$\begin{array}{l}\text { With whom } \\
\text { travelling }\end{array}$} & Alone & 15 & 4.2 \\
\hline & Family/Relatives & 240 & 67.0 \\
\hline & Friends & 83 & 23.2 \\
\hline & No response & 20 & 5.6 \\
\hline
\end{tabular}

Continued in the next column

was higher than 0.05 (Kalayc1, 2008). A pilot study was conducted with 40 foreign tourists visiting hotel enterprises in Marmaris between the dates of 1 and 15 April 2019. The Cronbach's Alpha value $(\alpha=0.908)$ regarding the 26 statements involved in the survey scale was determined to be quite reliable and the study continued.

According to the 358 population number, the Cronbach's Alpha $(\alpha)$ values of the scales used in the study were examined in order for their reliability and validity to be ensured. As seen in Table 1, it was determined that the hotel brand equity and perception of value co-creation dimensions in the conceptual model and the variable that has the highest reliability value within the wом variable $(\alpha=0.984)$ is the brand association variable and the variable that has the lowest reliability value $(\alpha=0.792)$ is the dialogue variable. It is seen that the Cronbach's Alpha values of all the variables used in the study are over $(\alpha) 0.70$ and adequately reliable (Hair et al., 2014).
Table 1 Continued from the previous column

\begin{tabular}{|c|c|c|c|}
\hline Category & Item & $n$ & $\%$ \\
\hline \multirow{8}{*}{$\begin{array}{l}\text { Household } \\
\text { annual income } \\
(\$)\end{array}$} & $<20,000$ & 43 & 12.0 \\
\hline & $20,000-29,999$ & 58 & 16.2 \\
\hline & $30,000-39,999$ & 51 & 14.2 \\
\hline & $40,000-49,000$ & 10 & 2.8 \\
\hline & $50,000-59,000$ & 76 & 21.2 \\
\hline & $60,000-69,000$ & 58 & 16.2 \\
\hline & $>70,000$ & 21 & 5.9 \\
\hline & No response & 41 & 11.5 \\
\hline \multirow{9}{*}{$\begin{array}{l}\text { Occupation } \\
\text { status }\end{array}$} & Manager & 85 & 23.7 \\
\hline & Retired & 49 & 13.7 \\
\hline & Self-employed & 37 & 10.3 \\
\hline & Worker & 107 & 29.9 \\
\hline & Student & 7 & 2.0 \\
\hline & Civil servant & 9 & 2.5 \\
\hline & Housewife & 7 & 2.0 \\
\hline & Other & 32 & 9.0 \\
\hline & No response & 25 & 7.0 \\
\hline
\end{tabular}

\section{Demographic Characteristics of Foreign Tourists}

The frequency and percentage distributions of the foreign tourists visiting Marmaris that were surveyed within the scope of the study can be seen in Table 1. The tourists' average age was determined to be 44 and their length of stay as 4 days. Accordingly, it was determined that $53.6 \%$ (192 people) of the participants are male, $46.4 \%$ (166 people) female, $45.8 \%$ (164 people) single, $39.9 \%$ (143 people) married and $14.2 \%$ (51 people) married with children. When the nationalities of the foreign tourists visiting Marmaris was examined, it was determined that $63.1 \%$ (226 people) are comprised of British tourists, $26.0 \%$ (93 people) are Dutch, 7.5\% (27 people) are Swedish and the remaining $3.4 \%$ (12) are of other nationalities (Irish, Scottish, German). When the levels of education of the tourists were examined, a $34.4 \%$ (123 people) majority was identified as college/university graduates. When whom the tourists travelled with was reviewed, it was determined that a large majority of $67.0 \%$ (240 peo- 
Table 2 Convergent and Discriminant Validity Values

\begin{tabular}{|c|c|c|c|c|c|c|c|c|c|c|c|c|}
\hline & $\mathrm{CR}$ & AVE & $\operatorname{MaxR}(\mathrm{H})$ & TRA & AWA & Ass & PQUAL & LOY & DIA & $\mathrm{ACC}$ & RISK & WOM \\
\hline TRA & 0.816 & 0.690 & 0.821 & 0.830 & & & & & & & & \\
\hline AWA & 0.955 & 0.913 & 0.955 & 0.608 & 0.956 & & & & & & & \\
\hline Ass & 0.984 & 0.969 & 0.985 & 0.620 & 0.788 & 0.985 & & & & & & \\
\hline PQUAL & 0.918 & 0.790 & 0.936 & 0.642 & 0.608 & 0.655 & 0.889 & & & & & \\
\hline LOY & 0.932 & 0.821 & 0.938 & 0.656 & 0.477 & 0.506 & 0.647 & 0.906 & & & & \\
\hline DIA & 0.729 & 0.576 & 0.758 & 0.814 & 0.552 & 0.600 & 0.699 & 0.732 & 0.759 & & & \\
\hline $\mathrm{ACC}$ & 0.913 & 0.777 & 0.916 & 0.744 & 0.574 & 0.607 & 0.666 & 0.658 & 0.923 & 0.881 & & \\
\hline RISK & 0.885 & 0.793 & 0.897 & 0.599 & 0.383 & 0.331 & 0.495 & 0.397 & 0.511 & 0.443 & 0.891 & \\
\hline WOM & 0.958 & 0.884 & 0.958 & 0.737 & 0.509 & 0.511 & 0.660 & 0.765 & 0.733 & 0.660 & 0.523 & 0.940 \\
\hline
\end{tabular}

Notes Column/row headings are as follows: $\mathrm{TRA}=$ Transparency, AWA $=$ Brand Awareness, Ass = Brand Association, PQUAL $=$ Perceived Quality, LOY = Loyalty, DIA $=$ Dialogue, $\mathrm{ACC}=$ Access, $\mathrm{RISK}=$ Risk, wOM $=$ Word of Mouth, $\mathrm{CR}=$ Composite Reliability, AVE = Average Variance Extracted. Diagonal values are square roots of AVE values per construct; off-diagonal values are the correlations of the variables.

ple) were travelling with Family/Relatives. In the annual household income, it is seen that $21.2 \%$ (76 people) are comprised of tourists within the income range between the $\$ 50,000-\$ 59,000$ interval. On the other hand, when their occupations were examined, it was determined that $29.9 \%$ (107 people) at most are comprised of workers. When all these results are generally reviewed, it can be said that most of the tourists visiting the hotel enterprises are comprised of individuals who are mostly male, British, University graduates, travelling with Family/relatives with an average annual income range between the $\$ 50,000-\$ 59$, 000 interval.

\section{Convergent and Discriminant Validity}

Within the scope of determining the reliability and validity of the study, the values of $\mathrm{CR}, \operatorname{AVE}, \operatorname{MaxR}(\mathrm{H})$ have been examined (Table 2). In order to establish CR (Convergent Reliability), it is expected that the CR should have values of 0.70 and higher and AVE (Average Variance Extracted) values should have values of 0.50 and higher (Byrne, 2010). That the AVE value is higher than 0.50 means that adequate levels of variance was explicated by variables relational to factors, and that the $\mathrm{CR}$ value is higher than 0.70 means that the factors have high internal reliability (Fornell \& Larcker, 1981). The facts that the $\operatorname{MaxR}(\mathrm{H})$ (Maximum $\mathrm{H}$ Reliability) value is higher than the $\mathrm{CR}$ value and that the square root of the AVE value is higher than the correlation values of that variable with other variables mean that discriminant validity is established (Fornell \& Larcker, 1981).

When Table 2 is reviewed, it is understood that the lowest AVE value calculated for the latent variables is 0.576 and the lowest CR value calculated is 0.729 , rendering the assumptions of convergent validity ensured. It is seen that the $\operatorname{MaxR}(\mathrm{H})$ value is higher than the $\mathrm{CR}$ value for each latent variable integrated into the model for divergent reliability. Again, it is seen that the square roots of the AVE value and the inter-variable correlation values are acceptable, thereby ensuring divergent validity for all latent variables.

\section{Exploratory Factor Analysis (efa) Results}

Initially, to test the structure validity of the scales used in the study, exploratory factor analyses have been carried out. For this reason, exploratory factor analyses have been carried out for the dimensions of brand equity and perception of value co-creation in the study scale. KMO and Bartlett's tests have been carried out initially in order to understand whether they are suitable for factor analysis. As a result of the EFA conducted, the кмо value has been determined as 0.873 and the Bartlett's test $\chi^{2}$ value has been determined as $4547.808(p<0.000)$. For the perception of value co- 
Table 3 Exploratory Factor Analysis of the Hotel Brand Equity variable, CFA and Second-Order CFA values

\begin{tabular}{|c|c|c|c|c|c|c|c|c|}
\hline \multicolumn{2}{|c|}{ Brand equity dimensions } & \multicolumn{4}{|c|}{ EFA values } & \multicolumn{3}{|c|}{ CFA values } \\
\hline & & \multirow{2}{*}{$\begin{array}{r}\begin{array}{r}\text { Std. } \\
\text { loadings }\end{array} \\
0.821\end{array}$} & \multirow{2}{*}{$\begin{array}{r}\begin{array}{r}\text { Variance } \\
\text { explained }\end{array} \\
62.602\end{array}$} & \multirow{2}{*}{$\begin{array}{r}\text { Eigenvalue } \\
6.886\end{array}$} & \multirow{2}{*}{$\begin{array}{r}\alpha \\
0.929\end{array}$} & \multirow{2}{*}{$\begin{array}{r}\begin{array}{r}\text { Std. } \\
\text { loadings }\end{array} \\
0.796\end{array}$} & \multirow{2}{*}{$\begin{array}{r}t \text { values } \\
21.096\end{array}$} & \multirow{2}{*}{$\begin{array}{r}P \\
0.001\end{array}$} \\
\hline Perceived quality & PQ3 & & & & & & & \\
\hline & $\mathrm{PQ} 1$ & 0.813 & & & & 0.940 & - & - \\
\hline & $\mathrm{PQ} 2$ & 0.808 & & & & 0.921 & 29.536 & 0.001 \\
\hline & PQ4 & 0.747 & & & & - & - & - \\
\hline \multirow[t]{3}{*}{ Loyalty } & LOY 2 & 0.877 & 14.527 & 1.598 & 0.930 & 0.945 & 25.516 & 0.001 \\
\hline & LOY 3 & 0.857 & & & & 0.862 & - & - \\
\hline & LOY 1 & 0.847 & & & & 0.908 & 23.991 & 0.001 \\
\hline \multirow[t]{2}{*}{ Brand awareness } & AWA 2 & 0.876 & 8.551 & 0.941 & 0.955 & 0.952 & - & - \\
\hline & AWA 1 & 0.860 & & & & 0.960 & 34.430 & 0.001 \\
\hline \multirow[t]{2}{*}{ Brand association } & Ass 2 & 0.800 & 4.531 & 0.498 & 0.984 & 0.979 & - & - \\
\hline & ASS 1 & 0.795 & & & & 0.990 & 60.177 & 0.001 \\
\hline \multicolumn{9}{|c|}{ Second-Order CFA analysis results } \\
\hline \multirow[t]{4}{*}{ Brand equity } & Perceived quality & - & - & - & - & 0.749 & 14.134 & 0.001 \\
\hline & Loyalty & - & - & - & - & 0.848 & 10.603 & 0.001 \\
\hline & Brand awareness & - & - & - & - & 0.858 & - & \\
\hline & Brand association & - & - & - & - & 0.894 & 16.886 & 0.001 \\
\hline
\end{tabular}

Notes Extraction method: Principal Component Analysis; Rotation method: Varimax Rotation. Goodness-of-fit statistics of CFA: $\Delta \chi^{2}=77.959, \mathrm{DF}=29, \chi^{2} / \mathrm{DF}=2.688, \mathrm{RMSEA}=0.069, \mathrm{CFI}=0.988, \mathrm{GFI}=0.959, \mathrm{IFI}=0.988$. Goodness-of-fit statistics of second order CFA: $\Delta \chi^{2}=125.097, \mathrm{DF}=31, \chi^{2} / \mathrm{DF}=4.035, \mathrm{RMSEA}=0.092, \mathrm{CFI}=0.977, \mathrm{GFI}=0.936, \mathrm{IFI}=0.977$.

creation dimensions, the кмо 0.896 and the Bartlett's test $\chi^{2}$ value has been determined as 2713.991 ( $p<$ 0.000 ) and these results show that it is suitable for factor analysis (Kalayc1, 2008).

In Table 3, initially, the EFA results for the expressions of the foreign tourists visiting the hotel enterprises in Marmaris regarding hotel brand equity dimensions are included in the study. As a result of the EFA conducted, it has been determined that the hotel brand equity dimensions involve a four-dimensional structure explaining $90.212 \%$ of the total variance and that each of the factor loads are over 0.32 (Tabachnick \& Fidell, 2007). As a result of the EFA, it has been determined that brand awareness, brand association, perceived quality and loyalty comprise the brand equity dimensions and factor loads are between 0.877 and 0.747 .

On the other hand, as seen in Table 4, E FA analy- sis has been conducted on the statements where there are the dimensions of tourists' perception of value co-creation. As a result of the EFA, it has been determined that the dimensions of the perception of value co-creation involve a fourfold structure explicating $78.070 \%$ of the total variance and that each of the factor loads are over 0.32 (Tabachnick \& Fidell, 2007). The dimensions which emerged are Dialogue, Transparency, Accessibility, Risk and Access, with their factor loads determined to be between 0.889 and 0.421 .

\section{Confirmatory Factor Analyses (CFA) for the Dimensions of Hotel Brand Equity and Perception of Value Co-Creation}

In order to be able to test the structure validity of the scales used, CFA was carried out on the dimensions of Hotel Brand Equity and Perception of Value CoCreation. Fit indices needed to be reviewed for the 
Table 4 EFA, CFA and Second-Order CFA values for the variable of the Perception of Value Co-Creation

\begin{tabular}{|c|c|c|c|c|c|c|c|c|}
\hline \multirow{2}{*}{$\begin{array}{l}\text { Perception of value } \\
\text { co-creation variables }\end{array}$} & & \multicolumn{4}{|c|}{ EFA values } & \multicolumn{3}{|c|}{ CFA values } \\
\hline & & Std. & Variance & Eigenvalue & $\alpha$ & Std. & $t$ values & $P$ \\
\hline \multirow[t]{3}{*}{ Access } & $\mathrm{ACC} 2$ & 0.889 & 51.363 & 6.164 & 0.911 & 0.898 & 25.068 & 0.001 \\
\hline & $\mathrm{ACC} 1$ & 0.852 & & & & 0.902 & - & - \\
\hline & $\mathrm{ACC} 3$ & 0.804 & & & & 0.842 & 22.035 & 0.001 \\
\hline \multirow[t]{3}{*}{ Risk } & RIS 2 & 0.869 & 12.913 & 1.550 & 0.835 & 0.967 & 13.779 & 0.001 \\
\hline & RIS 1 & 0.861 & & & & 0.818 & - & - \\
\hline & RIS 3 & 0.737 & & & & - & - & - \\
\hline \multirow[t]{3}{*}{ Transparency } & TRA 3 & 0.884 & 7.765 & 0.932 & 0.809 & - & - & - \\
\hline & TRA 2 & 0.688 & & & & 0.818 & 17.141 & 0.001 \\
\hline & TRA 1 & 0.607 & & & & 0.842 & - & - \\
\hline \multirow[t]{3}{*}{ Dialogue } & DIA 2 & 0.800 & 6.029 & 0.723 & 0.792 & - & - & - \\
\hline & DIA 1 & 0.670 & & & & 0.655 & - & - \\
\hline & DIA 3 & 0.421 & & & & 0.861 & 13.104 & 0.001 \\
\hline \multicolumn{9}{|c|}{ Second-order CFA analysis results } \\
\hline \multirow{4}{*}{$\begin{array}{l}\text { Perception of value } \\
\text { co-creation }\end{array}$} & Access & - & - & - & - & 0.907 & 12.045 & 0.001 \\
\hline & Risk & - & - & - & - & 0.534 & $7 \cdot 573$ & 0.001 \\
\hline & Transparency & - & - & - & - & 0.835 & 10.912 & 0.001 \\
\hline & Dialogue & - & - & - & - & 0.988 & - & - \\
\hline
\end{tabular}

Notes Extraction method: Principal Component Analysis; Rotation method: Varimax Rotation. Goodness-of-fit statistics of CFA: $\Delta \chi^{2}=52.216, \mathrm{DF}=21, \chi^{2} / \mathrm{DF}=2.486$, RMSEA $=0.065, \mathrm{CFI}=0.985$, GFI $=0.967$, IFI $=0.986$. Goodness-of-fit statistics of second order CFA: $\Delta \chi^{2}=78.934, \mathrm{DF}=23, \chi^{2} / \mathrm{DF}=3.432$, RMSEA $=0.083, \mathrm{CFI}=0.974, \mathrm{GFI}=0.952$, IFI $=0.974$.

CFA results obtained from the Amos software. Frequently reviewed indices among the fit indices are Chi-Square Fit test $\left(\Delta \chi^{2} \leq 5\right)$, root mean square error of approximation, RMSEA $(\leq 0.080)$, Goodness of Fit Index, GFI ( $\geq 0.80)$, Adjusted Goodness of Fit Index: AGFI ( $\geq 0.80)$, comparative fit index, CFI $(\geq 0.90)$, and incremental fit index, IF I $(\geq 0.90)$ (Schumacker \& Lo$\max , 2010$ ).

According to Table 3, hotel brand equity dimensions are subjected to CFA and the PQ4 statement were excluded from the study since its factor load was low and it reduced the goodness of fit values of the study. As a result of the repeated analysis, it was determined that the factor loads of all the statements are 0.50 (Kalayc1, 2008) and over. The goodness of fit values of the CFA for the hotel brand equity dimensions are $\Delta \chi^{2}=77.959 ; \mathrm{DF}=29 ; \chi^{2} / \mathrm{DF}=2.688 ; \mathrm{RM}-$
$\mathrm{SEA}=0.069 ; \mathrm{CFI}=0.988 ; \mathrm{GFI}=0.959 ; \mathrm{IFI}=0.988$. These results show that CFA has adequate goodness of fit values (Hair et al., 2014).

As a result of the CFA applied on the perception of value co-creation dimensions, the statements of TRA3, RIS3 and DIA 2 were excluded from the model since they had low factor load and they reduced the goodness of fit values. As a result of the repeated CFA analysis, it was determined that all the factor loads are over 0.50. The goodness of fit values of the CFA conducted for the perception of value co-creation dimensions are $\Delta \chi^{2}=52.216 ; \mathrm{DF}=21 ; \chi^{2} / \mathrm{DF}=2.486 ; \mathrm{RMSEA}=0.065 ;$ CFI $=0.985 ;$ GFI $=0.967 ; \mathrm{IFI}=0.986$ and it is seen that it has adequate goodness of fit values (Hair et al., 2014).

In order to reduce the hotel brand equity and perception of value co-creation dimensions which will 
be involved in the conceptual model to a single dimension, second-order CFA analyses have been conducted. The goodness of fit values of the second-order CFA conducted to reduce the hotel brand equity to a single dimension are $\Delta \chi^{2}=125.097 ; \mathrm{DF}=31 ; \chi^{2} / \mathrm{DF}$ $=4.035$; RMSEA $=0.092 ;$ CFI $=0.977$; GFI $=0.936$; IFI $=0.977$. On the other hand, the goodness of fit values of the second-order CFA conducted in order to reduce the dimensions of the perception of value co-creation to a single dimension are $\Delta \chi^{2}=78.934$; $\mathrm{DF}=23 ; \chi^{2} / \mathrm{DF}=3.432 ; \mathrm{RMSEA}=0.083 ; \mathrm{CFI}=0.974$; GFI $=0.952$; IFI 0.974. According to all of these results obtained, the second-order CFA analyses are determined to have the adequate goodness of fit values (Hair et al., 2014).

\section{Measurement Model and Testing the Hypothesis}

Through the study, the case of whether the primary condition of creating a model was fulfilled has been tested by analyzing the relations between the dimensions used in the study in hotel brand equity, perception of value co-creation and wom.

As a result of the measurement model carried out, it was determined that the apparent variables are in relation with their dependent latent variables and also that the relations between all variables are significant at the $p<0.05$ level and that the covariance values between variables are lower than $<0.85$. In order to elevate the goodness of fit values of the measurement model, adjustments have been made between the ACC1 (e15) and ACC3 (e17), ACC2 (e16) and ACC3 (e17) as well as wом2 (e25) and wом3 (e24), and the goodness of fit values were elevated. The goodness of fit criteria for all the variables for the measurement model were determined as $\Delta \chi^{2}=682.169 ; \mathrm{DF}=195$; $\chi^{2} / \mathrm{DF}=3.498 ; \mathrm{RMSEA}=0.084 ; \mathrm{CFI}=0.941 ; \mathrm{GFI}=$ 0.845 ; IF I $=0.942$. These results show that the goodness of fit values are adequate (Hair et al., 2014).

After the measurement models were confirmed, the relations between the variables used in the study were tested through the structural model. Within the scope of the structural model analysis, 3 different hypotheses were analyzed in order to determine the effects of hotel brand equity on the perception of value co-creation and wом along with perception of value

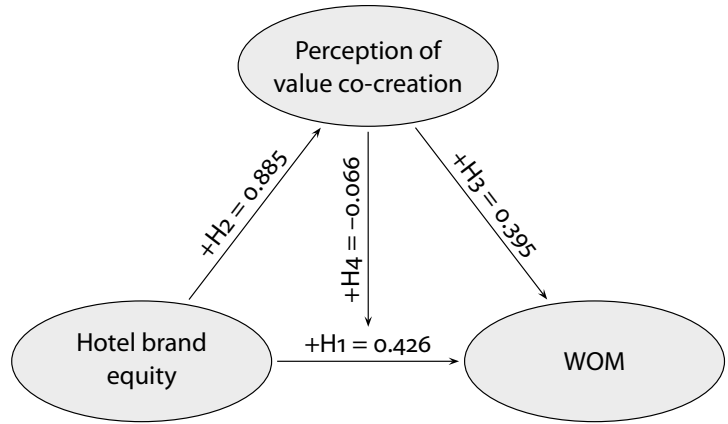

Figure 2 The Standardized Values Determined by the Conceptual Model

co-creation on wom. Another unique aspect of this study is that 1 (one) hypothesis has been tested in order to determine whether the hotel brand equity and its effect on шом has a moderator role on the perception of value co-creation. As a result of the structural model implemented in line with all these aims, the path diagram regarding the findings is seen in Figure 2. As seen in the path diagram, it was determined that there is a positive and significant effect of hotel brand equity on the perception of value co-creation and шом. Moreover, it was determined that the perception of value co-creation has a positive and significant effect on wom. Furthermore, it is seen in the model in Figure 2 that the variance exploration rate for the co-creation variable is $78.4 \%\left(R^{2}=0.784\right)$, and the variance exploration rate for the wом variable is $63.6 \%\left(R^{2}=0.636\right)$.

When the $t$ values in Table 5 are examined, it is seen that the significance level is higher than 2.56 and at $p$ $<0.001$ between the hotel brand equity and the perception of value co-creation and шом; and the perception of value co-creation and шом (Schumacker \& Lomax, 2010). Also, when the goodness of fit values for the path analysis regarding the significance of the structural model, it is seen that they are: $\Delta \chi^{2}$ $=682.169 ; \mathrm{DF}=195 ; \chi^{2} / \mathrm{DF}=3.498 ; \mathrm{RMSEA}=0.084$; $\mathrm{CFI}=0.941 ; \mathrm{GFI}=0.845$; IFI $=0.942$ and that these values are adequate goodness of fit values (Hair et al., 2014).

When the conceptual model in Figure 2 and the hypothesis results in Table 5 are examined, it is seen that the hotel brand equity of the foreign tourists vis- 
Table 5 Path Analysis and Hypothesis Results

\begin{tabular}{|c|c|c|c|c|c|}
\hline Hypotheses & Path Analysis & SRW & $t$ values & $p$ & Results \\
\hline$+\mathrm{H} 1$ & Hotel Brand Equity $\rightarrow$ wom & 0.426 & 3.670 & $0.001^{* * *}$ & Supported \\
\hline$+\mathrm{H}_{2}$ & Hotel Brand Equity $\rightarrow$ Perception of Value Co-Creation & 0.885 & 10.887 & $0.001^{* * *}$ & Supported \\
\hline$+\mathrm{H} 3$ & Perception of Value Co-Creation $\rightarrow$ wom & 0.395 & 3.434 & $0.001^{* * *}$ & Supported \\
\hline
\end{tabular}

Notes SRW - Standardized Regression Weights. ${ }^{* *} p<0.001$. Goodness-of-fit statistics of path analysis: $\Delta \chi^{2}=682.169, \mathrm{DF}$

$=195, \chi^{2} / \mathrm{DF}=3.498, \mathrm{RMSEA}=0.084, \mathrm{CFI}=0.941, \mathrm{GFI}=0.845, \mathrm{IFI}=0.942$.

Table 6 Path Analysis Results Showing the Moderating Effect $(n=358)$

\begin{tabular}{|c|c|c|c|}
\hline Variables & $\beta$ & SE & $t$ \\
\hline Hotel brand equity $(\mathrm{x})$ & $0.438^{\star *}$ & 0.054 & 7.922 \\
\hline Percept. of value co-creation (w) & $0.382^{* *}$ & 0.059 & 6.911 \\
\hline $\mathrm{X} . \mathrm{w}$ & $-0.066^{*}$ & 0.040 & -1.993 \\
\hline
\end{tabular}

iting hotel enterprises in Marmaris has a positive and significant effect on wом and perception of value cocreation (н1: $\beta=0.426, t=3.670, p=0.001 ; \mathrm{H} 2: \beta$ $=0.885, t=10.887, p=0.001)$. For this reason, the hypotheses of $\mathrm{H} 1$ and $\mathrm{H} 2$ formed as 'Hotel Brand Equity has a positive and significant effect on wom and perception of value co-creation' have been corroborated. Furthermore, it has been determined that perception of value co-creation has a positive and significant effect on wом (н3: $\beta=0.395, t=3.434, p=0.001)$. Therefore, the hypothesis $\mathrm{H} 3$, formed as 'Perception of value co-creation has a positive and significant effect on wom, has been corroborated.

In order to be able to test the moderator role of the perception of value co-creation on the effect of hotel brand equity on wом, path analysis has been carried out using the Amos software. In the path analysis conducted with the apparent variables, the method of calculating maximum likelihood has been used and its path analysis results are in Table 5. While the values for the estimation and the moderator variable were standardized beforehand, the values were centralized in order to minimize the multicollinearity issue. It is seen that all the estimation variables included in the

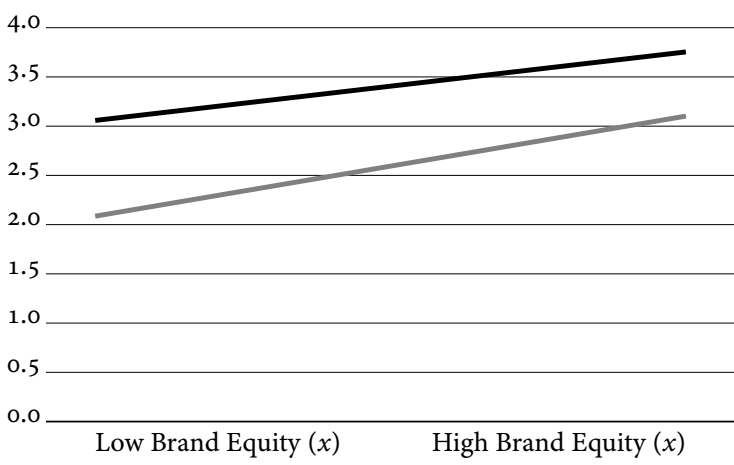

Figure 3 Graphic Representation of the Moderating Effect of the Perception of Value Co-Creation (light low Value Co-Creation ( $w$ ), dark - high Value Co-Creation $(w))$

path analysis explained $61 \%\left(R^{2}=0.608\right)$ of the change on шом. On шом, it has been determined that hotel brand equity $(\beta=0.438, p<0.001)$ and perception of value co-creation $(\beta=0.382, p<0.001)$ have a positive and significant effect. It has been ascertained that the hotel brand equity and perception of value co-creation variables' interactive effect (moderator effect) is significant and negative $(\beta=-0.066, p<0.05)$.

Determining the form and direction of the combined effect of the interaction between hotel brand equity and perception of value co-creation, in cases where the hotel brand equity was low and high, the opinions of those with high and low perception of value co-creation on wом are shown in Figure 3. Whether the slopes in Figure 3 differ at a significant level from the o (zero) value, has been tested with a slope test. As a result of the slope test, it has been determined that the correlation between hotel brand equity and шом is both high and that its correlation to the 
value co-creation is significant and positive $(\beta=0.44$, $p<0.001 ; \beta=0.38, p<0.001$, respectively). Consequently, it is seen that tourists with high levels of value co-creation perception carry more wo those with low perception of value co-creation when there is high hotel brand equity, and hypothesis $\mathrm{H} 4$ is accepted in this case. According to this result, it can be said that when hotel managers use the perception of value co-creation by taking hotel brand equity characteristics into consideration, they will increase wом. Furthermore, it is possible to state that although the relationship between hotel brand equity and шом is as claimed in the $\mathrm{H} 4$ hypothesis, according to the levels of the perception of value co-creation, this relation is thinning. In other words, according to the findings obtained, the relationship between hotel brand equity and шом is stronger in tourists who attribute low importance to the perception of value co-creation compared to those who attribute more importance to it.

\section{Discussion and Conclusion}

As the share of the service sector in the economy grows, the importance of participatory applications that are customer-based is gradually increasing. In Turkey as well, the largest share of the service sector is held by the tourism sector. The branding efforts of hotel enterprises as the locomotives of the sector, the effort to determine the value perceptions of customers and the results of these efforts being spread among the customers in a positive way have become prioritized.

According to the sources obtained as a result of the literature review carried out what was tested in general was whether hotel brand equity had any effect on wом, and no study has been found that suggests that the perception of value co-creation has a regulating effect. Therefore, in order to define the relationship between hotel brand equity, perception of value cocreation variable and wом of the tourists visiting hotel enterprises in Marmaris, and to determine whether the perception of value co-creation has a moderator effect on the relationship between hotel brand equity and wом, 4 hypotheses were constructed and all of them have been accepted. That the moderator effect has been ascertained can be seen as a justification for the study and its most prominent characteristic.
Four dimensions have been uncovered as a result of the EFA conducted on hotel brand equity. The dimensions are conceived as quality, loyalty, brand association and brand awareness. As a result of the EFA conducted on the dimensions of perception of value co-creation, a four-dimensional structure has been identified involving dialogue, risk, transparency and access. As a result of the subsequently conducted CFA analyses and second-order CFA analyses, they were integrated into the model with the names of hotel brand equity and perception of value co-creation and their relations with the other variables were examined.

According to the findings, it has been determined that tourists' hotel brand equity increases the perception of value co-creation and шом. These findings show similarity to many studies such as Moise et al. (2019), Sofiane (2019), and González-Mansilla et al. (2019). On the other hand, it has been determined that the perception of value co-creation affects wom. This state of affairs correlates with the findings obtained in Seifert and Kwon's (2020) study. The result to be obtained out of the value co-creation perception of the customers will result in positive or negative wom. Hotels are primarily obligated to understand the dimensions of hotel brand equity in order to make accurate diagnoses in the long run. The perception of value co-creation formed with well-understood hotel brand equity will lead to the forming of positive wом from the perspective of the customer.

Lastly, except for the findings of the study that overlap with the literature, as a distinctly revealed finding, it was seen that the perception of value co-creation has a negative moderator effect on the effects of hotel brand equity on шом. Hotel enterprises are one of the most important components of the tourism sector. Due to hotel enterprises being high-cost businesses, it is necessary for them to wish to create a feeling of being valued for the customer in order to render their customers loyal to the enterprise. It is evident that there is perception of value, and sharing their perceptions through wом rapidly as a result of developing the perception of being valued is quite important for hotel enterprises in the exponentially challenging competitive environment of the 21st century.

There are certain limitations in this study. It was 
carried out in the Marmaris destination and only applied to foreign tourists coming to hotels in the summer months of the year 2019. It is recommended that relevant studies need to be carried out so as to encompass other destinations and also to domestic tourists in order to prove generalizable.

\section{References}

Aaker, D. A. (1991). Managing brand equity. Free Press.

Abubakar, M. A. (2016). Does ешом influence destination trust and travel intention: A medical tourism perspective. Economic Research-Ekonomska Istraživanja, 29(1), 598-611.

Akgün, V. Ö., \& Akgün, A. (2014). Marka ve Marka Değeri Olgusu: Marka Değerinin Tespitine Yönelik Bir Uygulama. Selçuk Üniversitesi Sosyal ve Teknik Araştırmalar Dergisi, 8, 1-13.

Albarq, A. N. (2014). Measuring the impacts of online wordof-mouth on tourists' attitude and intentions to visit Jordan: An empirical study. International Business Research, $7(1), 14-22$.

Alves, H., Fernandes, C., \& Raposo, M. (2016). Value cocreation: Concept and contexts of application and study. Journal of Business Research, 69(5), 1626-1633.

Anderson, E. W. (1998). Customer satisfaction and word-ofmouth. Journal of Service Research, 1(1), 5-17.

Ansary, A., \& Hashim, N. M. H. N. (2018). Brand image and equity: The mediating role of brand equity drivers and moderating effects of product type and word of mouth. Review of Managerial Science, 12(4), 969-1002.

Bailey, R., \& Ball, S. (2006). An exploration of the meaning of hotel brand equity. Service Industries Journal, 26(1), 1538.

Barlow, J., \& Moller, C. (2008). Her Şikâyet Bir Armağandır. Rota Yayınları.

Boo, S., Busser, J., \& Baloglu. S. (2009). A model of customerbased brand equity and its application to multiple destinations. Tourism Management, 30(2), 219-231.

Broyles, S. A., Leingpibul, T., Ross, R. H., \& Foster, B. M. (2010). Brand equity's antecedent/Consequence relationships in cross-cultural settings. Journal of Product \& Brand Management, 19(3), 159-169.

Bryman, A., \& Cramer, D. (2001). Quantitative data analysis with sPss Release 10 for Windows. Routledge.

Byrne, B. M. (2010). Structural equation modeling with AMOs (and ed.). Routledge.

Cabiddu, F., Lui, T.-W., \& Piccoli, G. (2013). Managing value co-creation in the tourism industry. Annals of Tourism Research, 42, 86-107.
Cantallops, A. S. (2019). The impact of value co-creation on hotel brand equity and customer satisfaction. Tourism Management, 75(3), 51-65.

Chathoth, P. K., Ungson, G. R., Harrington, R. J., \& Chan, E. S. W. (2016). Co-creation and higher order customer engagement in hospitality and tourism services. International Journal of Contemporary Hospitality Management, 28(2), 222-245.

Chekalina, T., Fuchs, M., \& Lexhagen, M. (2014). A value cocreation perspective on Customer-Based Brand Equity model for tourism destinations - A case from Sweden. Matkailututkimus, 10(1), 8-24. https://journal.fi

/matkailututkimus/article/view/90897

Chekalina, T., Fuchs, M., \& Lexhagen, M. (2018). Customerbased destination brand equity modeling: The role of destination resources, value for money, and value in use. Journal of Travel Research, 57(1), 31-51.

Chou, C. Y., Huang, C. H., \& Lin, T. (2018). Organizational intellectual capital and its relation to frontline service employee innovative behavior: Consumer value co-creation behavior as a moderator. Service Business, $12(4), 663-684$.

Çınar, K., Parlakkaya, R., \& Bilim, Y. (2019). Tüketici Temelli Marka Denkliği Unsurlarının Marka Bağlılığına Etkisi: Otel İşletmeleri Üzerine Bir Araştırma. Journal of Tourism and Gastronomy Studies, 7(4), 2481-2512.

Davras, Ö. (2019). Tüketici Temelli Destinasyon Marka Değeri Modellemesi: Isparta Destinasyonu Örneği. Seyahat ve Otel İşletmeciliği Dergisi, 16(3), 515-532.

Dedeoğlu, B. B., Niekerk, M. V., Weinland, J., \& Celuch, K. (2019). Re-conceptualizing customer-based destination brand equity. Journal of Destination Marketing \& Management, 11, 211-230.

Dellarocas, C. (2003). The digitization of word of mouth: Promise and challenges of online feedback mechanisms. Management Science, 49(10), 1407-1424.

Ergün, G. S., \& Akgün, V. Ö. (2016). Ağızdan Ağıza İletişim Kavramının Önemi Üzerine Kuramsal Bir Çalışma: Turizm Araştırmaları İncelemesi. Selçuk Üniversitesi Sosyal ve Teknik Araştırmalar Dergisi, 12, 152-175.

Forgacs, G. (2003). Brand asset equilibrium in hotel management. International Journal of Contemporary Hospitality Management, 15(6), 340-342.

Fornell, C., \& Larcker, D. F. (1981). Evaluating structural equation models with unobservable variables and measurement error. Journal of Marketing Research, 18(1), 3950.

Frías Jamilena, D. M., Peña, A. I. P., \& Rodriguez-Molina, M. A. R. (2017). The effect of value-creation on consumer- 
based destination brand equity. Journal of Travel Research, 56(8), 1011-1031.

García, J. A. C., Galindo, A. D. V., \& Suárez, R. M. (2018). The effect of online and offline experiential marketing on brand equity in the hotel sector. Spanish Journal of Marketing - ESIC, 22(1), 22-41.

González-Mansilla, O., Berenguer-Contri, G., \& Serra-Cantallops, A. (2019). The impact of value co-creation on hotel brand equity and customer satisfaction. Tourism Management, 75(3), 51-65.

Gremler, D. (1995). Word-of-mouth communication: Causes and consequences. Marketing Review, 15(3), 54-58.

Grönroos, C. (2000). Service management and marketing: A customer relationship management approach (2nd ed.). John Wiley \& Sons.

Grönroos, C. (2011). Value co-creation in service logic: A critical analysis. Marketing Theory, 11(3), 279-301.

Hair, J., Black, W., Babin, B., \& Anderson, R. (2014). Multivariate data analysis (7th ed.). Pearson Education.

Huang, Z. J., \& Cai, L. A. (2015). Modelling consumer-based brand equity for multinational hotel brands - When hosts become guests. Tourism Management, 46(C), 431443.

Jalilvand, M. R., \& Samiei, N. (2012). The impact of electronic word of mouth on a tourism destination choice. Internet Research, 22(5), 591-612.

Kalaycı, Ş. (2008). sPss Uygulamalı Çok Değişkenli İstatistik Teknikleri (3rd ed.). Asil Yayın Dağıtım.

Kayaman, R., \& Arasli, H. (2007). Customer based brand equity: Evidence from the hotel industry. Managing Service Quality, 17(1), 92-109.

Keller, K. L. (1993). Conceptualizing, measuring, and managing customer-based brand equity. Journal of Marketing, $57(1), 1-22$.

Kim, H., \& Kim, W. G. (2005). The relationship between brand equity and firms' performance in luxury hotels and restaurants. Tourism Management, 26(4), 549-560.

Kim, S., Schuckert, M., Im, H. H., \& Elliot, S. (2017). An interregional extension of destination brand equity: From Hong Kong to Europe. Journal of Vacation Marketing, 23(4), 277-294.

Kotler, P. (2000). Marketing management. Prentice Hall.

Laczniak, R. N., DeCarlo, T. E., \& Ramaswami, S. N. (2001). Consumers'responses to negative word-of-mouth communication: An attribution theory perspective. Journal of Consumer Psychology, 11(1), 57-73.

Lee, H. A., Law, R., \& Murphy, J. (2011). Helpful reviewers in Tripadvisor, an online travel community. Journal of Travel \& Tourism Marketing, 28(7), 675-688.
Maduka, O. B. (2016). Effects of customer value co-creation on customer loyalty in the Nigerian service industry. International Journal of Business and Management, 11(12), 77-82.

Marangoz, A. Y., \& Aydın, A. Ö. (2021). Marka Otantikliği ve Marka Sadakati Arasındaki İlişkide Marka Aşkının Düzenleyici Rolü. Pazarlama ve Pazarlama Araştırmaları Dergisi, 14(1), 83-112.

Moise, M. S., Gil-Saura, I., Seric, M., \& Molina, M. E. R. (2019). Influence of environmental practices on brand equity, satisfaction and word of mouth. Journal of Brand Management, 26(3). https://doi.org/10.1057/s41262-019oo16o-y

Murtiasih, S., Sucherly, S., \& Siringoringo, H. (2014). Impact of country of origin and word of mouth on brand equity. Marketing Intelligence \& Planning, 32(5), 616-629.

Pike, S. (2009). Destination brand positions of a competitive set of near-home destinations. Tourism Management, 30(6), 857-866.

Pike, S. (2010). Destination branding case study: Tracking brand equity for an emerging destination between 2003 and 2007. Journal of Hospitality and Tourism Research, 34(1), 124-139.

Pike, S., \& Bianchi, C. (2016). Destination brand equity for Australia: Testing a model of Св в long-haul markets. Journal of Hospitality \& Tourism Research, 4o(1), 114-134.

Prasad, K., \& Dev, C. S. (200o). Managing hotel brand equity: Cornell Hotel and Restaurant. Administration Quarterly, 41(3), 22-31.

Prebensen, N. K., Kim, H. L., \& Uysal, M. (2016). Cocreation as moderator between the experience value and satisfaction relationship. Journal of Travel Research, 55(7), 934945.

Schumacker, R. E., \& Lomax, R. G. (2010). A beginner's guide to structural equation modeling (3rd ed.). Routledge.

Seifert, C., \& Kwon, W. (2020). sNs ewom sentiment: Impacts on brand value co-creation and trust. Marketing Intelligence \& Planning, 38(1), 89-102.

Seric, M., \& Gil-Saura, I. (2019). Understanding brand equity in hotel firms: What is the role of brand loyalty and satisfaction? International Journal of Contemporary Hospitality Management, 31(9), 3526-3546.

Seric, M., Gil-Saura, I., \& Mikulic, J. (2017). Customer-based brand equity building: Empirical evidence from Croatian upscale hotels. Journal of Vacation Marketing, 23(2), 133-144.

Seric, M., Mikulic, J., \& Gil-Saura, I. (2018). Exploring relationships between customer-based brand equity and 
its drivers and consequences in the hotel context: An impact-asymmetry assessment. Current Issues in Tourism, 21(14), 1621-1643.

Sijoria, C., Mukherjee, S., \& Datta, B. (2019). Impact of the antecedents of electronic word of mouth on consumer based brand equity: A study on the hotel industry. Journal of Hospitality Marketing \& Management, 28(1), 1-27.

Sofiane, L. (2019). The impact of consumer-based brand equity on word-of-mouth behavior. International Journal of Business and Social Science, 10(4), 75-85.

Sotiriadis, M. D., \& Zyl, C. V. (2013). Electronic word-of mouth and online reviews in tourism services: The use of twitter by tourists. Electronic Commerce Research, 13(1), 103-124.

Sürücü, Ö., Öztürk, Y., Okumuş, F., \& Bilgihan, A. (2019). Brand awareness, image, physical quality and employee behavior as building blocks of customer-based brand equity: Consequences in the hotel context. Journal of Hospitality and Tourism Management, 40(3), 114-124.

Tabachnick, B. G., \& Fidell, L. S. (2007). Using multivariate statistics (5th ed.). Pearson Education.

Uslu, A., Ergün, G. S., \& Karabulut, A. N. (2020). Otel İşletmelerinde Marka Denkliğinin Müşteri Memnuniyeti Üzerindeki Etkisi: Güven Değişkeninin Aracı Rolü. Türk Turizm Araştırmaları Dergisi, 4(3), 2264-2281.

Vargo, S. L., \& Lusch, R. (2004). Evolving to new dominant logic. Journal of Marketing, 68(1), 1-17.
Vargo, S. L., Maglio, P. P., \& Akaka, M. A. (2008). On value and value co-creation: A service systems and service logic perspective. European Management Journal, 26(3), 145-152.

Xu, J. B., \& Chan, A. (2010). A conceptual framework of hotel experience and customer-based brand equity: Some research questions and implications. International Journal of Contemporary Hospitality Management, 22(2), 174-193.

Xu, F., Bai, Y., \& Li, S. (2019). Brand awareness, image, physical quality and employee behavior as building blocks of customer-based brand equity: Consequences in the hotel context. Journal of Hospitality and Tourism Management, 40(3), 114-124.

Yang, Y., Liu, X., \& Li, J. (2015). How customer experience affects the customer-based brand equity for tourism destinations. Journal of Travel \& Tourism Marketing, 32(1), 97-113.

Yazgan, H. İ., Kethüda, Ö., \& Çatı, K. (2014). Tüketici Temelli Marka Değerinin Ağızdan Ağza Pazarlamaya Etkisi. Cumhuriyet Üniversitesi İktisadi ve İdari Bilimler Dergisi, 15(1), 237-252.

Yoo, B., \& Donthu, N. (2001). Developing and validating a multidimensional consumer-based brand equity scale. Journal of Business Research, 52(1), 1-14.

Zeithaml, V., Berry, L. L., \& Parasuraman, A. (1996). The behavioral consequences of service quality. Journal of Marketing, 6o(2), 31-46. 